\title{
Adoption of Small-Scale Irrigation Farming as a Climate-Smart Agriculture Practice and Its Influence on Household Income in the Chinyanja Triangle, Southern Africa
}

\author{
Nelson Mango ${ }^{1, *(\mathbb{D}}$, Clifton Makate $^{1}{ }^{(\mathbb{D}}$, Lulseged Tamene ${ }^{2}$, Powell Mponela ${ }^{2}$ (D) and \\ Gift Ndengu ${ }^{2}$ \\ 1 International Centre for Tropical Agriculture (CIAT), P.O. Box MP 228 Mt. Pleasant, Harare, Zimbabwe; \\ ruumakate@gmail.com \\ 2 International Centre for Tropical Agriculture (CIAT), c/o Chitedze Agricultural Research Station, \\ P.O. Box 158 Lilongwe, Malawi; lt.desta@cgiar.org (L.T.); powellmponel@gmail.com (P.M.); \\ g.ndengu@cgiar.org (G.N.) \\ * Correspondence: nelsonmango16@gmail.com; Tel.: +254-722270913
}

Received: 31 January 2018; Accepted: 10 April 2018; Published: 14 April 2018

\begin{abstract}
This article is concerned with the adoption of small-scale irrigation farming as a climate-smart agriculture practice and its influence on household income in the Chinyanja Triangle. Chinyanja Triangle is a region that is increasingly experiencing mid-season dry spells and an increase in occurrence of drought, which is attributed largely to climate variability and change. This poses high agricultural production risks, which aggravate poverty and food insecurity. For this region, adoption of small-scale irrigation farming as a climate-smart agriculture practice is very important. Through a binary logistic and ordinary least squares regression, this article determines factors that influence the adoption of small-scale irrigation farming as a climate-smart agriculture practice and its influence on income among smallholder farmers. The results show that off-farm employment, access to irrigation equipment, access to reliable water sources and awareness of water conservation practices, such as rainwater harvesting, have a significant influence on the adoption of small-scale irrigation farming. On the other hand, the farmer's age, distance travelled to the nearest market and nature of employment negatively influence the adoption of small-scale irrigation farming decisions. Ordinary least squares regression results showed that the adoption of small-scale irrigation farming as a climate-smart agriculture practice has a significant positive influence on agricultural income. We therefore conclude that to empower smallholder farmers to respond quickly to climate variability and change, practices that will enhance the adoption of small-scale irrigation farming in the Chinyanja Triangle are critical, as this will significantly affect agricultural income. In terms of policy, we recommend that the governments of Zambia, Malawi and Mozambique, which cover the Chinyanja Triangle, formulate policies that will enhance the adoption of sustainable small scale-irrigation farming as a climate-smart agriculture practice. This will go a long way in mitigating the adverse effects that accompany climate variability and change in the region.
\end{abstract}

Keywords: climate-smart agriculture; adoption; small-scale irrigation farming; household income; Chinyanja Triangle; Southern Africa

\section{Introduction}

The rural poor in Sub-Saharan Africa (SSA) earn their livelihoods mostly from climate-sensitive rainfed agriculture. Their production is typically limited to a 3-6-month rainy season and crops 
grown are mainly staple cereal crops meant to sustain their livelihoods [1]. However, the yields from these crops are subject to weather-driven fluctuations and are generally low. Dependence of smallholder farmers in SSA on such climate sensitive, seasonal staple production systems often leads them into multiple-scale poverty traps [2]. Additionally, this often makes economies in the region (SSA) vulnerable to climatic variability and change [3-5].

It therefore requires that African governments assist the smallholder farming sector to transform and adapt to the various challenges it faces, including climate variability and change. Gaining access to relevant climate-smart technologies and other sustainable productivity-improving practices that will enable them to increase farm productivity, achieve climate resilience, improve food security, nutrition, and income and achieve other developmental goals is therefore key [6,7]. Climate-smart agriculture may be defined as an approach for transforming and reorienting agricultural development under the new realities of climate change [8]. The most commonly used definition is provided by the Food and Agricultural Organisation of the United Nations (FAO), which defines climate-smart agriculture as "agriculture that sustainably increases productivity, enhances resilience (adaptation), reduces/removes greenhouse gases (mitigation) where possible, and enhances achievement of national food security and development goals". In this definition, the principal goal of climate-smart agriculture is identified as food security and development [8,9], while productivity, adaptation, and mitigation are identified as the three interlinked pillars necessary for achieving this goal.

Adopting improved land and water management practices amongst other sustainable technologies can assist smallholder farmers in SSA to achieve the aforementioned goals [6-9]. Some of these technologies may include improved water management in agriculture through the adoption of small-scale irrigation, use of improved crop varieties, fertilizers and other innovative practices more suited to their local conditions. Of interest is the adoption of small-scale irrigation, which currently does not play a significant role in African agriculture, especially as compared to other regions such as Asia and Latin America [10]. Statistics show that irrigated land in Africa as the proportion to cultivated land is only about $6 \%$ for Africa compared to $14 \%$ for Latin America and 37\% for Asia [11,12].

In the Southern African region where this study was conducted, agricultural practice can be grouped into three categories: small-scale farmers, emerging farmers and large-scale farmers. When defining farming practice, the land size alone is not adequate for classifying whether a farmer is a small-scale or a large-scale farmer. Classification should also be based on the general character of the business with labour supply as the principal factor [13]. Small-scale farmers are those who are mainly located in rural areas where agriculture is the main activity to alleviate poverty and they are challenged by a number of constraints to increase productivity [14]. Small-scale farmers differ by individual characteristics: the size of the farm system, proportion of crops sold, household expenditure patterns, distribution of factors of production between food crops and cash crops and off-farm activities. These differences mean that these farmers make different contributions toward their country's economy [15].

Small-scale irrigation is critically important as an innovative practice in smallholder agriculture in Africa [16]. This is because it improves farm productivity [16], farming systems adaptation to climate variability and change and achievement of household food security and national developmental goals. According to Kamwamba-Mtethiwa et al. [16], there is a lot of heterogeneity in what small-scale irrigation farming entails in Africa. It is characterized by the use of simple technologies to access water for irrigation. Burney and Naylor [1] defined water access technology as any method of moving water from its source to where it was previously unavailable. This includes all types of pumps from human powered, rope and treadle pumps to liquid fuel engine-driven systems and solar powered pumps as well as gravity/river diversion methods [17]. In SSA, a wide variety of such technologies has been introduced since the 1990s for small-scale irrigation development [17]. Gravity technology typically involves diverting water flow using open channels without pumping. Motorized systems include engine-driven pumps, while treadle and rope and washer pumps are manual and wind and solar use renewable energy [16]. Previously, most rural farmers in SSA had relied on traditional methods on small plots of land using, for example, shadoof, buckets, watering cans, calabashes or 
blocking streams [18]. It can also mean total area of land covered by the irrigation practice that is in place. This can be from less than half an acre of land to multi-farmer irrigation projects that serve farms larger than 5 ha in size [19]. In SSA, the adoption of small-scale irrigation farming is hugely important for smallholder farmers, especially when one considers that rainfall is highly unreliable and insufficient in many places [6,20]. Drought-especially mid-season-due to low and erratic rainfall poses high uncertainty and agricultural production risks in sub-Saharan Africa [21]. This leads to threats of widespread poverty and food insecurity. Small-scale irrigation is possibly a viable climate-smart agriculture technology to consider in SSA given that the continent has abundant freshwater resources from various lakes and river basins [10] even though their distribution is not even across agro-ecological zones. In addition, small-scale irrigation is an important step towards the intensification of farming systems [22] and in helping farmers ensure against drought risk and transform their farming activities [23,24].

There is limited literature on studies that assess the impacts of adopting small-scale irrigation on people's livelihoods in SSA. The scarcity is even worse if we are to consider studies that have analyzed the livelihood impacts of small-scale irrigation as a potential climate-smart agriculture technology - that is, evaluating the potential of small-scale irrigation to build the resilience of farming systems to climate variability and change. With increased threats from climate variability and change in various parts of the world, including SSA, studies to assess the effectiveness of small-scale irrigation adoption in sustainably increasing productivity and incomes should be a priority. Literature that discusses adoption of small-scale irrigation in general in SSA is available. In these literature, small-scale irrigation was found to improve income and food security in the Ambo district, the Ada Liben district, the Tigray region, the Southern Nations, Nationality and People's Region, and the Oromia region, all in Ethiopia [25-29]. Similarly, in Zimbabwe, Mudima [30] investigated five irrigation schemes for their livelihood impacts. The study shows that the irrigation schemes acted as sources of food security for the participants and their surrounding communities. The main livelihood contributions of the irrigation schemes came through increased productivity, stable production and incomes. In addition, the study found that members of the irrigation schemes never ran out of food supplies compared to their counterparts relying on rainfed agriculture.

In the Southern African region, not much land is under irrigation for both subsistence and commercial agriculture. However, areas with irrigation schemes can be categorized into four groups. First is the bureaucratically managed small-scale scheme in which farming is carried out by the government or its agencies on behalf of the farmers. Second is the community or garden scheme, which is usually very small and is maintained by community users with the main objective of subsistence farming. Community gardens share a similar infrastructure for water supply where small dams are usually used for the water supply. Third are the corporation-financed schemes in which governments provide support from infrastructure down to farm gate while farmers only contribute toward a subsidized water fee and make operational service and management decisions. Lastly are the large estate irrigation schemes that are managed by agents with the objective of maximizing the use of resources through the production of high-value crops, such as tea, coffee, etc. [19,31]. The other significant group of small-scale farmers is the independent irrigators. They have a private water supply, such as their own borehole, and their primary objective is to make a living out of farming where it is usually considered as an additional source of income. Independent irrigators are usually not being supported through funds but use their own or family capital accumulated over time. Moreover, there is a lack of support for specialized technical advice on cropping and irrigation management, which reduces their overall productivity. According to Delgado [32], independent irrigators can be differentiated on the basis that they buy their own inputs and sell produce independently wherever they choose. In this study, we focus on the independent irrigators as they form the majority in the study site.

In Zambia, Malawi and Mozambique where the study area falls, small-scale irrigation generally relies on residual moisture and it is practised along stream banks. Smallholder farmers benefit from either government established smallholder schemes operated by the governments or from 
self-help schemes run by the farmers. In some cases, they are supported by non-governmental organizations (NGOs). These schemes receive little or no formal technical support in design, operation and maintenance. In addition to schemes, other informal un-documented irrigation practices such as the use of buckets, watering cans and hosepipes have been in place for several decades. The areas being irrigated range from as small as $100-200 \mathrm{~m}^{2}$ with traditional approaches to $1000-2500 \mathrm{~m}^{2}$ and up to 50 ha when organized as a smallholder scheme [33-35]. See Table 1 for coverage of areas of irrigation land in Zambia, Malawi and Mozambique.

Table 1. The cultivated, potential irrigable and actual areas under irrigation in Malawi, Mozambique and Zambia.

\begin{tabular}{cccc}
\hline Country & $\begin{array}{c}\text { Cultivated Area } \\
\text { (ha) }\end{array}$ & $\begin{array}{c}\text { Total Potential Irrigable Area } \\
\text { (ha) } \mathbf{a}^{-}\end{array}$ & $\begin{array}{c}\text { Total Irrigated Area } \\
\text { (ha) }\end{array}$ \\
\hline Malawi & $2,440,000$ & $480,000\left(100,000^{\mathrm{b}}\right)$ & 60,000 \\
Mozambique & $4,435,000$ & $3,072,000$ & $200,000^{\mathrm{c}}$ \\
Zambia & $5,289,000$ & $2,750,000$ & 156,000 \\
\hline
\end{tabular}

Source: FAO [33-35]. ${ }^{\text {a }}$ Based on water availability and soil irrigability; ${ }^{\mathrm{b}}$ small-scale farms; ${ }^{\mathrm{c}}$ Northern Mozambique.

The main crops grown include vegetables, rice, bananas and some local varieties of sugarcane. In 2005, the irrigation water use efficiency on smallholder farms was around $25-50 \%$ due to higher loss experienced in surface irrigation. There have been improvements in irrigation as the sector is gradually being transformed from subsistence-oriented to high value marketed crops. Since smallholder agriculture is not capital intensive, it is promoted as an adaptation strategy for the recurrent droughts that are attributed to climate variability and change in the region. Most of the streams in the region are seasonal with torrential flows during the short wet season of 3-4 months. The greater part of the year has low flows. The ground and large river/lake basin water are considerable but has not been tapped for irrigation use. The main challenge in developing small-scale irrigation has been the insufficient institutional capacity at both national and local levels [36].

With regard to the views above, this article aims to analyze the adoption of small-scale irrigation as a climate-smart agriculture practice in the Chinyanja Triangle, southern Africa, and assess its contribution to people's livelihoods. More specifically, the article aims to identify factors that influence smallholder farmers' decisions to adopt small-scale irrigation and assess the influence of adoption on household incomes. Policy options for targeting out and upscaling small-scale irrigation adoption for effective adaptation to climate variability and change in the region are therefore proposed.

\section{Research Methods}

\subsection{Study Area Context and Sites}

The study was conducted in the Chinyanja Triangle and covered Furancungo (14.90 S; $33.61 \mathrm{E}$ ) in Tete Province of Mozambique, Budula-Siliya (13.71 S; 31.96 E) in Zambia's eastern province, as well as Linthipe (14.17 S; $34.12 \mathrm{E}$ ) and Nsipe (14.87 S; $34.75 \mathrm{E})$ in the central and southern regions of Malawi (Figure 1). The common denominator in this region is the inhabitants' mother tongue, Chichewa. This region forms a triangular shape. Culturally, the majority of people in the region share the same beliefs. It is hypothesized that they would share similar approaches to resource management, especially in terms of the land on which they depend for their livelihoods and the adoption of certain agricultural practices [37]. According to the characterization by scholars from the Consultative Group for International Agricultural Research (CGIAR) [38], 37.9\% of the area in the Chinyanja Triangle is under shrub cover, which is classified as closed-open deciduous trees. Tree cover occupies $31 \%$ of the study area. Cultivated and managed areas make up $24 \%$ of the area and water bodies occupy $4 \%$. Herbaceous species cover $2.04 \%$ of the site and bare, artificial and associated areas take up less than $1 \%$. The study sites are dominated by maize as the staple food crop, mixed with legumes and groundnuts. 


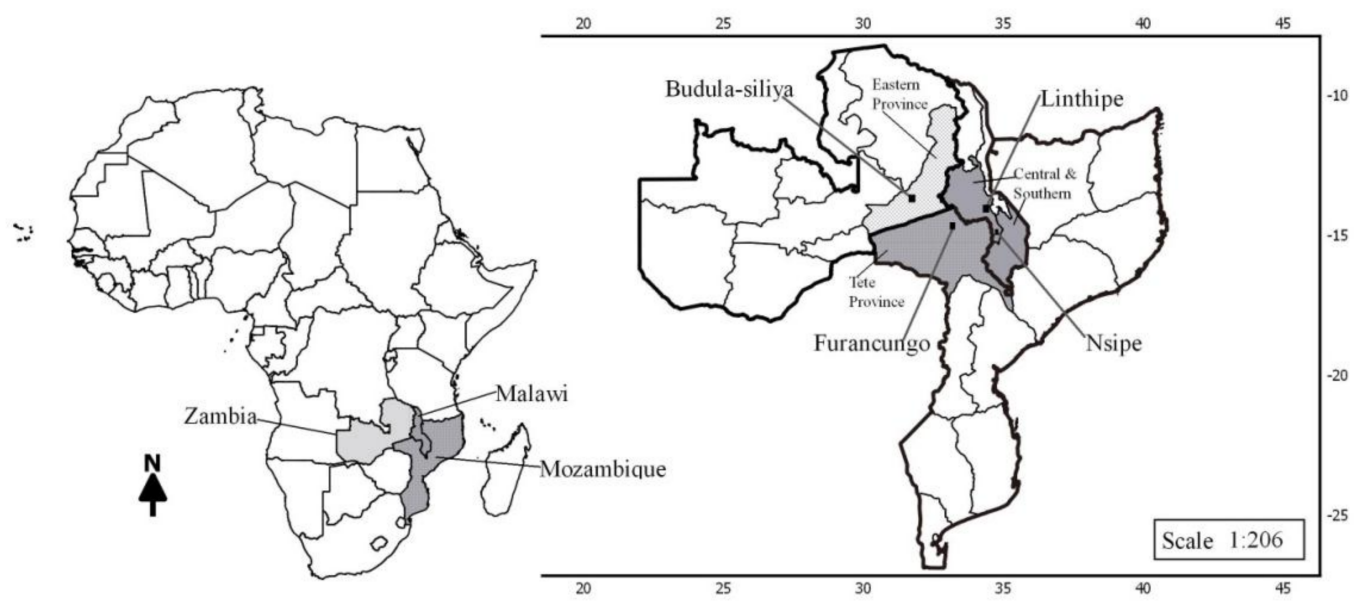

Figure 1. Map showing the location of the Chinyanja Triangle and research sites. The numbers on the map are the latitude and longitude of the specific research locations in degrees.

In terms of irrigation and water management, farming in the Chinyanja Triangle is mainly rainfed. This is despite the abundance of water resources within its catchment area, mainly from the Zambezi River Basin [37]. Irrigated agriculture contributes to less than $10 \%$ of the produce [39]. The general trends in the region show that climate variability and change pose a great risk to agriculture productivity. The unpredictable climate of the Chinyanja Triangle means that the risk of crop loss in rainfed agriculture exceeds $50 \%$ and can reach up to $75 \%$ in the drier southeastern zones of the triangle, including most parts of Tete Province of Central Mozambique [37-39]. On the other hand, the western and northern parts of the triangle have conditions that are more conducive for rainfed agriculture where the probability of good harvests during the wet season is 70-95\% [40].

Irrigation development is considered as a strategy for poor small-scale farmers to get out of poverty by shifting towards market-oriented agriculture [39]. Higher-value crops are grown in the valley bottoms mainly under irrigation or the dambo (wetland valley bottom) system. This is done as a response to climate variability and change in the region. In the dambo system, crops use residual moisture along with some supplementary irrigation to ensure adequate water supply during the growing period. Farmers also practice spate irrigation, furrow irrigation and, in a few cases, motorized pumps to deliver water to fields. The relatively higher-income and middle-income farmers are commonly the ones using motorized pumps while the low-income farmers use predominantly furrow irrigation or manual treadle pumps to transfer water from small springs [37].

The food crops commonly grown under irrigation include maize, rice, sweet potatoes, Irish potatoes, beans, leafy vegetables, tomatoes and onions. This is also where most farmers use external inputs (fertilizers and pesticides), particularly for growing cash crops such as tobacco and cotton. Most farmers have agricultural land to grow food crops and a few cash crops but not everyone has a garden area because of limited access to irrigation water. Malawi's renewable water resource is estimated to be $17.28 \mathrm{~km}^{3} \mathrm{yr}^{-1}$ of which about $16.14 \mathrm{~km}^{3} \mathrm{yr}^{-1}$ is produced internally, drained from the rivers within the country [40]. About $91 \%$ of the country is within the Zambezi River Basin, over $90 \%$ formed by the Shire Basin. According to FAO [33-35] and the Department of Irrigation in Malawi, the estimated irrigation potential in the country is about 480,000 ha while only 63,000 ha have been fully developed, of which $77 \%$ is used by commercial estates whilst only $23 \%$ is used by smallholders $[40,41]$ who produce mainly cereals (mostly rice and maize) and horticultural crops. Among those parcels that are irrigated, $62 \%$ use watering cans, $14 \%$ use flooding, $11 \%$ are gravity-fed and $6 \%$ use treadle pumps [ 42 ]. Peters [41] estimated that about 11,500 ha of the small-scale irrigation are under farmer-run self-help irrigation schemes while 3,200 ha are under government-run irrigation schemes. The irrigated area in estates is used for export- or high-value crops such as sugarcane (45\%), tea (44\%) and coffee (11\%) [43]. Moreover, about 62,000 ha of land is estimated to be used for traditional wetland cultivation using 
residue moisture, mainly during the dry seasons as the areas are waterlogged and inaccessible during the rainy season. There is no formal classification of smallholder irrigation schemes in Malawi but they are informally classified as farmer-run self-help schemes or government-run irrigation schemes. The latter schemes commonly target smallholder farmers but are managed and rehabilitated, where necessary, by the government, commonly using donor funding. Because there was limited participation in the design, construction and management of the irrigation schemes, government-run irrigation schemes managed by settlers and smallholders are underperforming and are the least diversified in terms of market opportunities. Their landholdings are also small, even by Malawi standards, each being between 0.1 and 0.3 ha [43] — too small to support substantial livelihoods.

Zambia has a huge irrigation potential, estimated to be about 2.75 Mha of land [40], with a large portion of it being in the Chinyanja Triangle. However, the total area currently under irrigation is estimated to be only about $10 \%$ of the potential and is mostly practised by large- and medium-scale farmers using surface water irrigation [44]. Only 15,000 ha of land is estimated to be irrigated with motor pumps although the region holds a high groundwater potential that could be exploited by increasing access to motor pumps. Most of the smallholder-irrigation schemes produce food crops, such as rice, maize and horticultural crops, but they are usually underperforming due to poor infrastructure, inadequate water supply, and inefficient use of the available water [43]. The high rainfall from December to March commonly saturates the soil and creates seasonally waterlogged low-lying dambos. There is potential for developing and expanding small reservoirs in the region for multiple uses, namely drinking for livestock, fishery, household irrigation and other domestic uses [44].

Mozambique has more than 100 river basins. Most of the rivers have highly seasonal, torrential flow regimes with high flow for 3-4 months and low flow for the remainder of the year, corresponding to the distinct wet and dry seasons [39]. Among these, the Zambezi River Basin is the most important in Mozambique [37]. It accounts for about $50 \%$ of the surface water resources of the country and about $80 \%$ of its hydropower potential, including the Cahora Bassa Dam [40], the second largest dam in Africa. The main source of water for irrigation in Mozambique is surface water. Irrigation in Mozambique is in its infancy despite being a downstream country with large seasonal flows of the region's big rivers, including the Limpopo and the Zambezi. The irrigation potential is estimated to be above 3 Mha but only a small part of it is being developed, primarily for the large-scale production of sugarcane, rice and vegetables in the downstream, central and southern provinces. Tete Province, which is within the Chinyanja Triangle, has limited surface water flow except in districts at higher altitudes (e.g., Angonia) [37]. Small-scale irrigation is very much limited to surface water irrigation for producing tobacco, vegetables and a few rice fields. Mozambique could expand its provision of water to smallholder farmers, particularly in the Chinyanja Triangle, to mitigate the potential effects of recurrent drought. With the increasing market opportunities in Tete and its surroundings, thanks to the expanding mining sector, small-scale irrigation could help farmers produce high-value agricultural products, access regional markets and improve their capacity to respond to emerging demands and climatic shocks [37]. Vegetables, fruits, dairy and small ruminant production seem to be feasible entry points. In terms of irrigation technology, motor pumps could play an important role in the near future in that landscape in getting water to farmers' fields although the governments in the three countries are promoting the use of treadle pumps because of the low maintenance requirements and operational costs.

In general, there is an increasing trend to use water for multiple purposes in the entire Chinyanja Triangle socio-technical landscape, particularly in Malawi through integrating fishponds into farming practices, drinking for livestock, irrigation farming and household use. Those farmers who have adopted aquaculture have doubled their household income and increased household food production by about $150 \%$ [45]. This compensates for crop losses due to climate change and variability. The adoption of fishponds has been growing in number by about $25 \% \mathrm{yr}^{-1}$ since 2000 and is being increasingly practised in the region, particularly in the lower Zambezi River Basin [45]. Governments have also acknowledged the challenge of promoting this practice in areas where the total rainfall amount is low and access to the Zambezi River or its tributaries is limited [37]. However, increased 
integration of fishponds into farming systems along with the increasing demand for irrigation water has created a fierce local competition among and between communities [37]. Expansion of small-scale irrigation systems coupled with ineffective institutions for water governance for multiple demands has led to frequent water shortages and local conflicts among communities.

\subsection{Sampling Methods, Data Collection and Data Source}

\section{Sampling and Data Collection}

Sampling units for this study were drawn using the multistage spatially stratified random sampling design of the Land Degradation Surveillance Framework [46]. Four sites, as described in Section 2.1, were used to make up the sample data. There were 16 clusters within each site. For the Africa Rising sites, the two mother trials (established during the 2012/13 growing season) were used as centre clusters with the other 14 clusters randomly spread around them. Each cluster covered an area of $2 \mathrm{~km}^{2}$ with 10 randomly located sampling plots from where a Land Condition Survey (LCS) was conducted. For each cluster, five farmers who owned odd numbered plots (1, 3, 5, 7 and 9) were considered for a socioeconomic questionnaire. The socioeconomic data were collected from owners of the plots sampled during the LCS, thereby geo-referencing farmers to their sampled plots and not their place of residence. Plot owners were identified during the LCS by locals from the nearest village. The household survey was conducted to collect primary household socioeconomic data using structured questionnaires. Collected data included the socio-demographic and economic characteristics of the households, land characteristics and integrated soil fertility management (ISFM) technology usage, livestock ownership and species, as well as irrigation and water harvesting technology practices. Extension service personnel, agriculture research officers and trained enumerators collected data between December 2012 and June 2013. Data on different livestock species were further converted into standard livestock units (LUs) using nutritional and feed requirement factors for sub-Saharan Africa [47,48].

Data were collected from 312 households. In this context, a household was defined as a group of people who normally live together and eat their meals in the same dwelling [49]. The data obtained were used to estimate the binary logistic and ordinary least squares (OLS) regression models. For the purposes of this study, the heads of the selected households, whether male or female, were implicitly assumed to be the sole decision-makers in the adoption of irrigation farming decisions. Household heads were therefore selected to respond to the structured questionnaire. Predictor variables of adoption were selected from the broad range of the household's socioeconomic aspects, including demographics, farming activities, institutions, processes of adoption and asset endowment.

\subsection{Data Analysis}

In this article, both descriptive and econometric data analysis methods were used. Where land holdings are fixed, the allocation of land into crop type and the adoption of small-scale irrigation farming are possibly endogenous. The adoption decision of small-scale irrigation farming as a climate-smart agriculture practice and associated technologies is distinct, as a farmer can decide to adopt or not adopt, in which case the smallholder farmer faces a dichotomous decision problem to adopt or not adopt irrigation farming. In this context, smallholder irrigation farming adopters practised irrigation farming at the time of the survey, while the rest were taken as non-adopters. In this study, irrigation farming was mainly practised in the forms of spate, furrow and surface water irrigation with a few farmers using manual and or motorized treadle pumps as discussed in the previous sections. A smallholder farmer was considered an adopter of small-scale irrigation if he/she was practising at least one of the aforementioned irrigation types as a response to climate variability and change in the region. On the other hand, those farmers who did not practise any of the irrigation farming methods were considered as non-adopters. Similar definitions of adopters and non-adopters have been used by other writers [50]. In the OLS-based impact analysis, only farmers who had practised irrigation farming for at least one season were considered as adopters. The econometric models for adoption 
and the model on the effect of the adoption of small-scale irrigation farming on income are specified in the section below.

Modelling the Adoption of Small-Scale Irrigation Farming as a Climate-Smart Agriculture Practice

The general assumption was that there is a desire to maximize the expected utility of adopting new technologies such as small-scale irrigation farming given the persistent drought in the region [22,51]. Although the utility-maximizing objective of individual smallholder farmers everywhere might be the same, the specific characteristics that influence their technology adoption decisions are far from uniform. The farmers' responses to the adoption of small-scale irrigation farming as a climate-smart agriculture practice were assumed to be consistent with utility maximization. Binary logistic regression is a common statistical procedure in which the probability of a dichotomous outcome (adoption or non-adoption) is related to a set of explanatory variables and has been widely applied in adoption studies [48,50,52-61]. In this research, smallholder farmers' adoption of small-scale irrigation farming as an adaptation strategy to climate change was based on an assumed underlying utility function. According to this model, the farmer will adopt small-scale irrigation farming if the utility obtained from small-scale irrigation farming exceeds that of non-adoption. Considering the probability of an event $=$ Prob ( $\mathrm{Y}=1$ if the smallholder farmer adopted and 0 otherwise), the smallholder farmer's behaviour towards irrigation farming is described as an indirect utility that is derived from the adoption of small-scale irrigation farming, which is a linear function of $k$ explanatory variables $(\mathrm{X})$ expressed as:

$$
\mathrm{Z}_{\mathrm{i}}=\beta_{0}+\sum_{i=1}^{n} \beta_{i} X_{k i}
$$

where $\beta_{0}$ is the intercept term and $\beta_{1}, \beta_{2}, \beta_{3}, \ldots, \beta_{i}$ are the coefficients associated with each of the $k$ explanatory variables $\left(X_{1}, X_{2}, X_{3}, \ldots, X_{k i}\right)$. The $X$ vector of variables (including socioeconomic, farming, institutional factors and other household-specific characteristics that influence the individual farmer's decision whether to adopt or not) explains the adoption of irrigation farming by the smallholder farmer, i.e., it explains the likelihood of the adoption of irrigation farming by the individual $\left(i_{\text {th }}\right)$ farmer (see Table 2).

Considering $P_{i}=\frac{e^{z i}}{1+e^{z i}}$, where $P_{\mathrm{i}}$ denotes the probability of the $i$ th farmer's adoption decision and $\left(1-P_{i}\right)$ is the probability of non-adoption, the odds of adoption $(Y=1)$ versus the odds of non-adoption $(\mathrm{Y}=0)$ can be defined as the ratio of the probability that a farmer adopts $\left(P_{i}\right)$ to the probability of non-adoption $\left(1-P_{i}\right)$, namely odds $=P_{i} /\left(1-P_{i}\right)$ [62]. By taking the natural logarithms, one gets the prediction equation for the individual farmer:

$$
\operatorname{Ln}\left(\frac{P_{i}}{1-P_{i}}\right)=\beta_{0}+\sum_{i=1}^{n} \beta_{i} X_{k i}=Z_{i}
$$

where $Z_{\mathrm{i}}$ is referred to as the odds ratio in favour of the adoption of irrigation farming.

\subsection{Variable Selection and Hypothesis on Adoption Decisions Model}

Table 2 gives a full description of the dependent variable, explanatory variables and initial hypotheses of selected predictor variables on adoption decisions. Previous studies on the adoption of agricultural technologies, such as the determinants of micro-irrigation adoption [63-65], economic theory on adoption and the researchers' own perceptions of the socioeconomic setting of the study locations guided the selection of variables and their expected signs [49,51-61]. The study therefore considered the characteristics of the household head and the household itself including gender, age, household size, education, off-farm employment and occupation. The household's access to various assets such as extension and agricultural credit, reliable water reservoirs, irrigation equipment (such as manual and motorized pumps) and land was determined. Other explanatory variables included the distance to the nearest markets and knowledge of conservation practices. It is important to note that 
access to irrigation equipment (manual and or motorized pumps) also acted as a proxy for general access to resources (affluent farmers).

Table 2. Description of the variables specified in the binary logistic model of adoption.

\begin{tabular}{|c|c|c|c|c|}
\hline Variable Acronym & Description & Measurement & $\begin{array}{l}\text { Posited } \\
\text { Sign }\end{array}$ & Supporting References \\
\hline \multicolumn{5}{|l|}{ Dependent variable } \\
\hline Irrigation farming & $\begin{array}{l}\text { Whether farmer adopted } \\
\text { irrigation farming or not }\end{array}$ & Dummy ( 1 if yes, 0 if no) & + & {$[19,20,44,45,51,53,63,64]$} \\
\hline \multicolumn{5}{|l|}{$\begin{array}{l}\text { Explanatory } \\
\text { variables }\end{array}$} \\
\hline Gender & $\begin{array}{l}\text { Gender of household } \\
\text { head }\end{array}$ & $\begin{array}{l}\text { Dummy ( } 1 \text { if male, } 0 \text { if } \\
\text { female) }\end{array}$ & + & {$[19,20,44,45,52,54,64]$} \\
\hline Age & Age of household head & Years & - & {$[44,45,51,54,64,66-69]$} \\
\hline Household size & Household size & Numbers & + & {$[19,20,44,45,51,54,64]$} \\
\hline Education & $\begin{array}{l}\text { Educational background } \\
\text { of the household head }\end{array}$ & $\begin{array}{l}\text { Number of years of } \\
\text { formal education }\end{array}$ & + & {$[19,20,44,45,51,54,64]$} \\
\hline Extension & $\begin{array}{l}\text { Access to agricultural } \\
\text { extension services }\end{array}$ & Dummy ( 1 if yes, 0 if no) & + & {$[19,20,44,45,51,54,64]$} \\
\hline Occupation & $\begin{array}{l}\text { Nature of the main } \\
\text { occupation of the } \\
\text { household head }\end{array}$ & $\begin{array}{c}1 \text { if farming, } 2 \text { if formal } \\
\text { employment, } 3 \text { if } \\
\text { small-scale business, } 4 \text { if } \\
\text { casual labour, and } 5 \text { if } \\
\text { skilled labour }\end{array}$ & $+/-$ & {$[19,20,44,45,51,54,64]$} \\
\hline $\begin{array}{c}\text { Off-farm } \\
\text { employment }\end{array}$ & $\begin{array}{c}\text { Members of the } \\
\text { household with off-farm } \\
\text { employment }\end{array}$ & Numbers & - & {$[19,20,44,45,51,54,64,70-72]$} \\
\hline Credit access & Access to credit & Dummy ( 1 if yes, 0 if no) & + & {$[19,20,44,45,51,54,64]$} \\
\hline $\begin{array}{l}\text { Irrigation } \\
\text { equipment }\end{array}$ & $\begin{array}{c}\text { Household's access to } \\
\text { irrigation equipment }\end{array}$ & Dummy ( 1 if yes, 0 if no) & + & {$[19,20,44,45,51,54,64]$} \\
\hline $\begin{array}{l}\text { Reliable water } \\
\text { source }\end{array}$ & $\begin{array}{l}\text { Access to a reliable water } \\
\text { source that can be used } \\
\text { for irrigation purposes }\end{array}$ & Dummy ( 1 if yes, 0 if no) & + & {$[52,54,66]$} \\
\hline $\begin{array}{c}\text { Awareness of } \\
\text { conservation } \\
\text { practices }\end{array}$ & $\begin{array}{l}\text { Awareness of some of } \\
\text { the water conservation } \\
\text { practices, such as } \\
\text { rainwater harvesting }\end{array}$ & Dummy ( 1 if yes, 0 if no) & + & {$[40,43,45,52,54,66]$} \\
\hline $\begin{array}{l}\text { Distance to market } \\
\text { (square root) }\end{array}$ & $\begin{array}{c}\text { Distance to the nearest } \\
\text { market (square root) }\end{array}$ & Kilometres & - & {$[37,42,52,54,66]$} \\
\hline $\begin{array}{l}\text { Land size } \\
\text { cultivated }\end{array}$ & $\begin{array}{l}\text { Size of land available } \\
\text { for cultivation }\end{array}$ & Hectares & $+/-$ & {$[19,22,36,47,52,54,66]$} \\
\hline
\end{tabular}

\subsubsection{Validity of the Binary Logistic Model}

Coefficients of the binary logistic model were estimated by the maximum likelihood method using STATA 12 software. The results of the binary logistic model are given in Table 4 . The number of observations used in the model is 312 . Prob $>C h i 2=0.000$ and a pseudo $\mathrm{R}^{2}$ of $42.2 \%$ shows that the model is valid and the model estimates fit very well with the data at an acceptable level.

\subsubsection{Modelling Effect of the Adoption of Irrigation Farming on Income}

The continuous dependent variable is agricultural income. As such, the OLS regression model can be used without a doubt. Getacher et al. [50] have also used the approach to estimate the effect of irrigation technology adoption on total agricultural income. To estimate the effect of the adoption of 
irrigation farming on household agricultural income, a multiple OLS regression model was used that is specified as follows:

$$
Y_{i}=\beta_{0}+X_{1 i} \beta_{1}+X_{2 i} \beta_{2}+\cdots \ldots . .+X_{k i} \beta_{k}+p_{i} \beta_{k+1}+\varepsilon_{i}
$$

where $Y_{i}=$ agricultural income; $X_{k i}$ is a vector of the household's socioeconomic characteristics and other farm-specific characteristics. These characteristics include livestock units (LUs), contact with agricultural extension and labour; $p_{i}$ denotes the adoption of small-scale irrigation farming status for a farmer; a dummy variable is specified as 1 for adopters and 0 for non-adopters; and $\varepsilon_{i}$ is the error term, which is assumed to be normally distributed with a mean of 0 and unit (constant) variance.

Table 3 shows the explanatory variables used in the OLS regression model with their specifications.

Table 3. Description of the variables specified in the ordinary least squares (OLS) regression model.

\begin{tabular}{|c|c|c|c|c|}
\hline Acronym & Description & Type of Measure & $\begin{array}{l}\text { Posited } \\
\text { Sign }\end{array}$ & Supporting References \\
\hline \multicolumn{5}{|l|}{ Dependent variable } \\
\hline $\begin{array}{l}\text { Agricultural } \\
\text { income }\end{array}$ & $\begin{array}{l}\text { Income from agricultural } \\
\text { production }\end{array}$ & US\$ & + & {$[50,57-61]$} \\
\hline \multicolumn{5}{|l|}{$\begin{array}{l}\text { Explanatory } \\
\text { variables }\end{array}$} \\
\hline Irrigation farming & $\begin{array}{l}\text { Whether farmer adopted } \\
\text { irrigation farming or not }\end{array}$ & Dummy ( 1 if yes, 0 if no) & + & {$[19,22,38,47,52,54,57-61]$} \\
\hline Extension & $\begin{array}{l}\text { Access to agricultural } \\
\text { extension services }\end{array}$ & Dummy ( 1 if yes, 0 if no) & + & {$[19,22,38,47,52,54,61-66]$} \\
\hline $\begin{array}{l}\text { Land size } \\
\text { cultivated }\end{array}$ & $\begin{array}{l}\text { Size of land available for } \\
\text { cultivation }\end{array}$ & Hectares & $+/-$ & {$[19,22,38,47,52,54,61-66]$} \\
\hline Labour & Labour force size & $\begin{array}{c}\text { Active labour force } \\
\text { members }\end{array}$ & + & {$[19,22,38,47,52,54,61-66]$} \\
\hline $\begin{array}{l}\text { Economically } \\
\text { active }\end{array}$ & $\begin{array}{l}\text { Economically active } \\
\text { population }\end{array}$ & Numbers & $-/+$ & {$[47,52,54,61-66]$} \\
\hline $\begin{array}{c}\text { Off-farm } \\
\text { employment }\end{array}$ & $\begin{array}{l}\text { Members of the } \\
\text { household with off-farm } \\
\text { employment }\end{array}$ & Numbers & - & {$[19,20,44,45,51,54,57-62,70-72]$} \\
\hline Group membership & $\begin{array}{l}\text { Household member } \\
\text { belongs to a farmer } \\
\text { group }\end{array}$ & Dummy ( 1 if yes, 0 if no) & + & {$[19,22,38,47,52,54,61-66]$} \\
\hline Livestock units & Livestock units & Numbers & + & {$[50,57-61]$} \\
\hline Main crop & $\begin{array}{l}\text { Main crop grown by } \\
\text { household }\end{array}$ & $\begin{array}{c}1 \text { if cereal, } 2 \text { if } \\
\text { horticultural, } 3 \text { if mixed }\end{array}$ & $+/-$ & {$[19,22,38,47,52,54,57-61]$} \\
\hline $\begin{array}{l}\text { Distance to market } \\
\text { (square root) }\end{array}$ & $\begin{array}{l}\text { Distance to the nearest } \\
\text { market (square root) }\end{array}$ & Kilometres & - & {$[37,42,52,54,66]$} \\
\hline Literacy & $\begin{array}{l}\text { Level of literacy in the } \\
\text { household }\end{array}$ & Numbers & + & [57-61] \\
\hline $\begin{array}{l}\text { Adoption of Land, } \\
\text { Soil and Water } \\
\text { (LSW) }\end{array}$ & $\begin{array}{l}\text { Household adopted any } \\
\text { available Land, Soil and } \\
\text { Water, conservation } \\
\text { practices }\end{array}$ & Dummy ( 1 if yes, 0 if no) & $+/-$ & {$[19,22,38,47,52,54,57-61]$} \\
\hline
\end{tabular}

\subsubsection{Descriptive Statistics of Variables Used in the Two Econometric Models}

The statistics of the variables specified in the two empirical models (the adoption of irrigation farming model and the income model), as shown in Tables 2 and 3, are given in Table 4. The table shows summary statistics on the profile of enumerated smallholder farmers. 
Table 4. Statistics of variables used in the econometric models.

\begin{tabular}{ccccc}
\hline Variable & Mean & $\begin{array}{c}\text { Standard } \\
\text { Deviation } \boldsymbol{n = 3 1 2}\end{array}$ & $\begin{array}{c}\text { Minimum } \\
n=\mathbf{3 1 2}\end{array}$ & $\begin{array}{c}\text { Maximum } \\
n=\mathbf{3 1 2}\end{array}$ \\
\hline Age & 46.589 & 15.308 & 20 & 90 \\
Household size & 5.837 & 2.379 & 1 & 15 \\
Education & 5.045 & 3.637 & 0 & 17 \\
Extension & 0.692 & 0.462 & 0 & 1 \\
Occupation & 1.311 & 0.909 & 1 & 5 \\
Off-farm employment & 0.776 & 1.354 & 0 & 8 \\
Credit access & 0.237 & 0.426 & 0 & 1 \\
Irrigation equipment & 0.333 & 0.472 & 0 & 1 \\
Reliable water source & 0.487 & 0.501 & 0 & 1 \\
Awareness of conservation practices & 0.792 & 0.407 & 0 & 1 \\
Distance to market & 30.142 & 21.135 & 0.3 & 95 \\
Distance to market (square root) & 5.133 & 1.951 & 0.55 & 9.75 \\
Land size cultivated & 6.126 & 7.041 & 0.3 & 41 \\
Labour & 3.288 & 1.807 & 0 & 12 \\
Economically active & 2.824 & 1.754 & 0 & 10 \\
Off-farm employment & 0.776 & 1.354 & 0 & 8 \\
Group membership & 0.340 & 0.474 & 0 & 1 \\
Livestock units & 1.457 & 4.093 & 60 \\
Main crop & 1.154 & 1.109 & 0 & 14 \\
Literacy & 2.458 & 1.970 & 0 & 11 \\
Adoption of LSW & 0.712 & 0.454 & 0 & 1 \\
Irrigation farming & 0.471 & 0.50 & & 1 \\
\hline
\end{tabular}

\section{Results and Discussion}

\subsection{Results of the Model and Discussion}

Table 5 reports the coefficients (B), standard errors of the coefficients (S.E), odds ratios and the $p$-values. Odds ratios show the predicted change in odds for a unit increase in the corresponding explanatory variable. Expressed in terms of variables used in the model, the logistic regression equation is:

$$
\begin{aligned}
\operatorname{Ln}\left(\frac{P_{i}}{1-P_{i}}\right) & =\operatorname{Ln}(\text { Odds }) \text { (reporting coefficients of only significant variables }) \\
& =-(0.040 * \text { Age })-(2.813 * \text { formal employment })-(1.462 * \text { small }- \text { scale business })+ \\
& (0.604 * \text { off }- \text { farm employment })+(0.706 * \text { irrigation equipment })+(2.921 * \text { reliable water source })+ \\
& (0.964 * \text { awareness of conservation practices })-(0.199 * \text { distance to market }(\text { square root }))
\end{aligned}
$$

These estimates provide information on the relationship between the significant explanatory variables and their influence on the adoption of irrigation farming as a climate-smart agriculture practice within the study area, where the dependent variable is on the logit scale.

The results of the logit model (Table 5) show that among the hypothesized explanatory variables only eight significantly influenced the adoption of irrigation farming. Age, formal employment, small-scale business, off-farm employment, irrigation equipment, reliable water sources, awareness of conservation measures and distance to the nearest market were the significant variables in the binary logistic model. Contrary to the hypothesis, gender, household size, education, extension, casual labour, skilled labour, credit access and land size cultivated did not significantly influence the adoption of small-scale irrigation farming.

Age had a negative impact on the adoption of small-scale irrigation farming, which suggests that the odds of adoption are higher among younger farmers than among older farmers. Specifically, the results show that a one-year increase in the farmer's age reduced the odds of adoption by about $4 \%$ ( 1 to 0.96 ). The average age of 46 for a population with a life expectancy of 40 shows that most farmers are ageing. As farmers get older, despite their accumulated experience in farming, they tend 
to lose energy, have short planning horizons and become more risk averse and therefore adopting new irrigation practices may be difficult for them. This result was expected and is consistent with other scientists' findings [66-69]. Moreover, small-scale irrigation farming is time and labour intensive. The proper management of irrigable crops (especially fruit and vegetables) also requires storage and transportation facilities, as well as market availability and access to the market, which act as an adoption barrier to the older farmers.

Table 5. Parameter estimates of the binary logistic regression model for factors influencing the adoption of irrigation in the Chinyanja Triangle.

\begin{tabular}{ccccc}
\hline Variable & B & (S.E) & Odds Ratio & $(p$-Value) \\
\hline Gender & 0.543 & 0.452 & 1.721 & 0.229 \\
Age *** & -0.040 & 0.012 & 0.961 & $0.001^{* * *}$ \\
Household size & 0.046 & 0.074 & 1.047 & 0.537 \\
Education & 0.011 & 0.05 & 1.011 & 0.830 \\
Extension & -0.482 & 0.383 & 0.618 & 0.208 \\
Occupation & & & & \\
formal employment *** & -2.813 & 0.983 & 0.060 & $0.004^{* * *}$ \\
Small-scale business * & -1.462 & 0.794 & 0.232 & $0.066^{*}$ \\
Casual labour & -1.554 & 1.653 & 0.211 & $0.347^{*}$ \\
Skilled labour & -1.099 & 0.924 & 0.333 & 0.234 \\
Off-farm employment *** & 0.604 & 0.179 & 1.829 & $0.001^{* * *}$ \\
Credit access & -0.171 & 0.414 & 0.843 & 0.680 \\
Irrigation equipment ${ }^{* *}$ & 0.706 & 0.358 & 2.027 & $0.049^{* *}$ \\
Reliable water source *** & 2.921 & 0.367 & 18.564 & $0.000^{* * *}$ \\
Awareness of conservation practices ** & 0.964 & 0.471 & 2.623 & $0.041^{* *}$ \\
Distance to market (square root) ${ }^{*}$ & -0.199 & 0.104 & 0.819 & $0.055^{*}$ \\
Land size cultivated & 0.006 & 0.023 & 1.006 & 0.811 \\
constant & -0.381 & 0.925 & 0.683 & 0.680 \\
\hline
\end{tabular}

${ }^{* * *}=1 \%$ level of significance, ${ }^{* *}=5 \%$ level of significance, ${ }^{*}=10 \%$ level of significance.

The household head's occupation was another variable that was thought to influence the adoption of small-scale irrigation farming. In terms of the sub-categories of the nature of employment, formal employment and small-scale business were found to have a significant negative impact on the adoption of small-scale irrigation farming. The odds of adoption were found to decrease if the household head's main occupation was either formal employment or involvement in a small-scale business. A probable explanation is that for households with formal employment and those involved in small-scale businesses, time will be the major limiting factor when it comes to focusing on agricultural activities. Household heads will tend to focus more on their work and small businesses and, as a result, the adoption of small-scale irrigation farming becomes more difficult. This finding agrees with that of Abera [70] who argued that irrigation is generally a labour- and time-intensive endeavour and that households usually find it difficult to synchronize small-scale irrigation farming with other off-farm activities.

In addition, the number of household members with off-farm employment was found to significantly influence the adoption of small-scale irrigation farming. The predicted change in the adoption of small-scale irrigation farming was found to be 1.83 for an increase in membership of the household by one with off-farm employment. This could probably be because if some members of the household are involved in off-farm activities, they play a supportive role in agricultural practices, especially by providing an alternative source of agricultural financing. Therefore, an increase in household members with off-farm employment increases the chances of adoption because of its supportive role. This result is consistent with that of Namara et al. [71] who concluded that off-farm employment activities improve income for the farmer and that income can be used to complement agricultural activities. However, the result was not as expected but was still acceptable as the empirical 
studies by Herath and Takeya [72] noted the role of off-farm income in the adoption of agricultural practices as unclear and a contested terrain.

As expected, access to irrigation equipment influenced the adoption of small-scale irrigation farming positively and significantly at a $5 \%$ level. The odds of adoption were found to be 2.03 times greater for farmers with access to irrigation equipment compared to those without access. Access to irrigation equipment necessitates the adoption of small-scale irrigation farming. Moreover, access to a reliable water source that can be used for irrigation also influenced the adoption of small-scale irrigation farming as expected. The odds of adoption were 18.6 times greater for farmers with access to reliable water sources-such as for farmers whose fields neighboured rivers and small water channels-compared to farmers without reliable water access. The results thus highlight the importance of the necessary irrigation equipment and reliable water sources (i.e., proximity to a perennial water source such as river or dam) in setting up successful small-scale irrigation farming systems. Based on the binary logistic model, access to irrigation equipment and a reliable water source are vital for any farmer to try small-scale irrigation farming.

Awareness of water conservation practices such as rainwater harvesting was also selected as an explanatory variable to explain variability in the adoption of small-scale irrigation farming. Results show that awareness of water conservation practices within the study sites had a positive and significant influence on the adoption of small-scale irrigation farming. The odds of the adoption of small-scale irrigation farming were found to be 2.62 times greater for farmers who were aware of water conservation methods practiced within the study sites compared to those who were not aware of such methods. This could be because the farmers who were aware of water conservation practices were more likely to adopt such practices. This necessitates the adoption of small-scale irrigation farming, since earlier results indicate that access to reliable water sources positively influenced the adoption of irrigation farming. Besides, farmers who had installed rainwater harvesting technologies, such as water tanks, would divert more of their time to adopt small-scale irrigation practices in riparian areas instead of going to fetch water for domestic use.

The distance travelled to access the nearest market was another variable that was thought to influence the adoption of small-scale irrigation farming. The results show that the distance travelled to access input and/or output markets had a significant negative influence on the adoption of irrigation farming. Odds of adoption decreased by about $18 \%$ with a one-kilometre increase in distance to the nearest input or output market for the farmer. This might be explained by the fact that most smallholder farmers now appreciate the role of markets in their farming activities. As a result, access to markets influences their farming intensification decisions. Farmers closer to input markets are motivated to adopt small-scale irrigation farming as a climate-smart agriculture practice since they realize that their production will be improved and they can easily sell the surplus at nearby markets. For farmers who travel long distances to access output markets, the situation might be very different. As much as they realize the importance of the adoption of small-scale irrigation farming in raising agricultural output, they may be discouraged to adopt the practice when they plan to sell their surpluses because long distances come with additional marketing costs, which they cannot afford.

Overall, the results point to important behavioural, market, institutional, organizational, social and economic factors that influence the adoption of small-scale irrigation farming as a climate-smart agriculture technology in the Chinyanja Triangle. Such factors can be a crucial input to scaling up of small-scale agriculture within the Chinyanja Triangle for greater, positive livelihood impacts on the society.

\subsection{Impact of the Adoption of Small-Scale Irrigation Farming on Income}

The adoption of small-scale irrigation farming was hypothesized to positively influence smallholder farmers' agricultural income. In the OLS-based impact analysis, the dependent variable was agricultural income. The adoption of small-scale irrigation farming was selected as an independent variable to explain the variations in agricultural income. The results of the analysis are shown in Table 6. 
Table 6. Impact of the adoption of irrigation farming on agricultural income: OLS results.

\begin{tabular}{|c|c|c|c|}
\hline Square Root of Agriculture Income & Coefficient & Standard Error & $p$-Value \\
\hline Irrigation farming ** & 2.052 & 0.940 & $0.030^{* *}$ \\
\hline Extension & 1.70 & 0.972 & $0.081 *$ \\
\hline Land size cultivated & 0.097 & 0.067 & 0.147 \\
\hline Labour ** & 0.645 & 0.318 & $0.043^{* *}$ \\
\hline Economically active & -0.371 & 0.315 & 0.240 \\
\hline Off-farm employment & -0.173 & 0.373 & 0.643 \\
\hline Group membership & 0.620 & 0.989 & 0.531 \\
\hline Livestock units & -0.087 & 0.116 & 0.452 \\
\hline Main crop * & 0.747 & 0.399 & $0.062 *$ \\
\hline Distance to market (square root) * & 0.423 & 0.256 & $0.099 *$ \\
\hline Literacy & 0.036 & 0.264 & 0.893 \\
\hline Adoption of LSW ** & -2.247 & 1.004 & $0.026 * *$ \\
\hline _constant ${ }^{* *}$ & 5.979 & 1.780 & $0.001^{* * *}$ \\
\hline
\end{tabular}

As expected, the results confirm that the adoption of small-scale irrigation farming as a climate-smart agriculture practice within the Chinyanja Triangle explains the variation in agricultural income. The adoption of small-scale irrigation farming was found to have a significant positive impact (at a 5\% level) on agricultural income. This could be because farmers who use small-scale irrigation farming can intensify and diversify their agricultural activities, which increases their production. This was confirmed by Singh et al. [73] and Hussain et al. [74] in their studies on the adoption of small-scale irrigation farming to be effective in reducing poverty due to improved productivity and greater returns from farming. Increased production will lead to increased income from agriculture (through the sale of surpluses), all things being equal. This is also influenced by market access, which is a driver or an incentive to stay engaged in farming. With small-scale irrigation, farmers can produce off-season as they can supplement their crops with water in the case of mid-season dry spells or shortages. In other words, small-scale irrigation farming reduces climate risks, improves crop production and reduces agricultural production's overdependence on rainfall [50,75]. This is also consistent with literature that ascertained the positive impacts of small-scale irrigation in developing areas on livelihood outcomes such as yield and income [27-29], poverty reduction [25], and food security $[19,26]$. These findings are also confirmed by studies in India by Chambers [76] who found that reliable and adequate irrigation increases employment opportunities and income, which ultimately contributes to food security. The result also bears important implications for climate change adaptation in smallholder agriculture within the Chinyanja Triangle. Small-scale irrigation is therefore a vital technology that can help reduce crop production risks posed by variable climate in the area and this can ultimately lead to more climate resilient livelihoods within the area. Related, Kumar [77] also confirmed the positive effects of small-scale irrigation in boosting India's food production and generating surpluses that can be used as a drought buffer.

Factors such as access to extension, labour, crops grown, distance to the nearest market, and the adoption of land, soil and water conservation practices also had a significant influence on agricultural income.

\section{Conclusions, Implications and Policy Recommendations}

This study was undertaken to improve our understanding of how efforts to promote the adoption of small-scale irrigation farming as a climate-smart agriculture practice can influence the income of smallholder farmers in the Chinyanja Triangle. Several useful conclusions that provide insight into pathways to increase smallholder farmers' adoption of small-scale irrigation farming in the study area and improve agricultural income have emerged from this research. 
First, the results indicate that promoting small-scale irrigation farming as a climate-smart agriculture practice for adoption by smallholder farmers should consider the farmer's age, main occupation, off-farm employment status, access to and availability of micro-irrigation equipment, water source reliability, awareness of certain water conservation measures and distance to the nearest markets. Failure to consider these socioeconomic aspects may lead to inappropriate results when aiming for higher rates of adoption of small-scale irrigation farming as a climate-smart agriculture practice in the study area. For example, the rehabilitation of reliable water sources will be an important move that can positively impact the adoption of small-scale irrigation farming. In addition, assisting farmers to access intermediary irrigation farming technologies and equipment will also enhance adoption. Raising farmers' awareness of water conservation practices, such as rainwater harvesting methods and techniques, through extension or any other means will be critical for improving the uptake of small-scale irrigation farming. Increased adoption of small reservoirs in the Chinyanja Triangle could be an important investment in the region to improve access to water, sustain multiple uses, support soil and water conservation, drought proofing and supplementary irrigation during dry spells. The overall trajectory in the high rainfall areas of the Chinyanja Triangle is to promote small-scale irrigation and to integrate irrigation into the social and economic context of the entire landscape.

Secondly, the results suggest that succeeding in enhancing the adoption of small-scale irrigation farming as a climate-smart agriculture practice through careful consideration of the socioeconomic aspects and other farm-specific attributes will enhance farmers' income. This is an important finding since the main motivation for urging farmers to adopt this technology is their welfare. Enhancing the adoption of small-scale irrigation farming within the Chinyanja Triangle will be a great step towards improving farmers' agricultural income and combating climate variability and change. This is supported by studies from India that show that adopting small-scale irrigation farming creates employment opportunities both on and off the farm that transforms into improved livelihoods and quality of life in the countryside [26,74,78].

Although our study makes a notable contribution to the adoption and impact of small-scale irrigation in smallholder farming, it is not without limitations. We relied on cross-sectional household level data, which in itself is associated with limitations (cf. [79]). It is therefore plausible that dynamics of irrigation farming adoption and impacts could be slightly biased due to the cross-sectional nature of our data. In light of this potential weakness, reliance on longitudinal data sets in future studies may give outcomes that are more robust. Other limitations noted in the study include insufficient institutional capacity both at the central and local levels. These were found to be the major constraint hampering the development of the small-scale irrigation subsector as a climate variability and change adaptation strategy. The institutions dealing specifically with irrigated agriculture are severely constrained by insufficiently qualified human resources and an inadequate budget (cf. [37]). A point of concern for the development of irrigation as a whole is the lack of flexibility of the legal and political framework concerning access to and use of land and water.

In view of the above, we recommend that the three governments (Zambia, Malawi and Mozambique) that cover the Chinyanja Triangle formulate national and regional policies on small-scale irrigation farming that will ensure that farmers do not suffer total loss of their agricultural produce due to climate variability and change. Currently, such policies in the three countries are wanting as they are not enforced and farmers and extension agents are left to confront the effects of climate variability and change on their own. Given that climate variability and change is increasingly becoming a reality in Africa, climate-smart agriculture practices such as small-scale irrigation farming need to be given emphasis.

Acknowledgments: The authors would like to acknowledge the financial assistance received from the Dryland Systems Consultative Research Programme (CRP1.1) that was used in carrying out this study. The authors would also like to acknowledge the support of Janine Smit Editorial Services that helped with language editing and proofreading of this article. We thank all the enumerators for good work in data collection and most importantly to farmers who patiently gave us their time and responded to our questions. 
Author Contributions: L.T., N.M., P.M. and G.N. conceived and designed the study; P.M. and G.N. conducted fieldwork; C.M., analyzed the data; N.M., and C.M., wrote the paper; L.T., P.M. and G.N. revised and reviewed the paper.

Conflicts of Interest: The authors declare no conflict of interest.

\section{References}

1. Burney, J.A.; Naylor, R.L. Smallholder Irrigation as a Poverty Alleviation Tool in Sub-Saharan Africa. World Dev. 2012, 40, 110-123. [CrossRef]

2. Barrett, C.B.; Swallow, B.M. Fractal poverty traps. World Dev. 2006, 34, 1-15. [CrossRef]

3. Barnichon, R.; Peiris, S.J. Sources of inflation in sub-Saharan Africa. J. Afr. Econ. 2008, 17, 729-746. [CrossRef]

4. Conway, G.; Waage, J.; Delaney, S. Science and Innovation for Development; UK Collaborative on Development Sciences (UKCDS): London, UK, 2010.

5. Davies, M.; Guenther, B.; Leavy, J.; Mitchell, T.; Tanner, T. Climate change adaptation, disaster risk reduction and social protection: Complementary roles in agriculture and rural growth? IDS Work. Pap. 2009, 1-37. [CrossRef]

6. FAO. Sourcebook on Climate Smart Agriculture, Forestry and Fisheries; Food and Agriculture Organization: Rome, Italy, 2013.

7. SciDev.Net African Smallholder Farmers Need Tech to Spur Food Security. 2014. Available online: https:/ / www.scidev.net/sub-saharan-africa/agriculture/news/african-smallholders-need-techsto-spur-food-security.html (accessed on 12 March 2018).

8. Lipper, L.; Thornton, P.; Campbell, B.M.; Baedeker, T.; Braimoh, A.; Bwalya, M.; Caron, P.; Cattaneo, A.; Garrity, D.; Henry, K.; et al. Climate-smart agriculture for food security. Nat. Clim. Chang. 2014, 4, 1068-1072. [CrossRef]

9. FAO. Climate-Smart Agriculture: Sourcebook; Food and Agriculture Organization of the United Nations: Rome, Italy, 2013.

10. You, L.; Ringler, C.; Wood-Sichra, U.; Robertson, R.; Wood, S.; Zhu, T.; Nelson, G.; Guo, Z.; Sun, Y. What is the irrigation potential for Africa? A combined biophysical and socioeconomic approach. Food Policy 2011, 36, 770-782. [CrossRef]

11. AQUASTAT; Food and Agriculture Organization (FAO): Rome, Italy, 2009.

12. NEPAD; AU. Sustainable Land and Water Management. In The CAADP Pillar 1 Framework; New Partnership for African Development and African Union: Midrand, South Africa, 2009.

13. Carver, T.N. Large-Scale and Small-Scale Farming. Am. Stat. Assoc. 1911, 12, 488-489. [CrossRef]

14. Kirsten, J.F.; Van Zyl, J. Defining small-scale farmers in the South African context. Agrekon 1998, 37, 551-562. [CrossRef]

15. Machingura, C. An Analysis of Factors That Can Be Used to Identify Successful Smallholder Farmers: A Case Study of Mbhashe and Ngqushwa. Master's Thesis, Department of Agricultural Economics and Extension, University of Fort Hare, Alice, South Africa, 2007.

16. Kamwamba-Mtethiwa, J.; Weatherhead, K.; Knox, J. Assessing Performance of Small-Scale Pumped Irrigation Systems in Sub-Saharan Africa: Evidence from a Systematic Review. Irrig. Drain. 2016, 65, 308-318. [CrossRef]

17. Namara, R.E.; Gebregziabher, G.; Giordano, M.; De Fraiture, C. Small pumps and poor farmers in Sub-Saharan Africa: an assessment of current extent of use and poverty outreach. Water Intern. 2013, 38, 827-839. [CrossRef]

18. Baba, K.M. Irrigation development strategies in sub-Saharan Africa: A comparative study of traditional and modern irrigation systems in Bauchi State of Nigeria. Agric. Ecosyst. Environ. 1993, 45, 47-58. [CrossRef]

19. Bembridge, T. Guidelines for Rehabilitation of Small-Scale Farmer Irrigation Schemes in South Africa; WRC Report 891/1/00; Water Research Commission: Pretoria, South Africa, 2000.

20. You, L.Z. Irrigation investment needs in sub-Saharan Africa. In A Report Produced for the World Bank by the Environment and Production Technology Division; International Food Policy Research Institute (IFPRI): Washington, DC, USA, 2008. 
21. Archer, E.; Mukhala, E.; Walker, S.; Dilley, M.; Masamvu, K. Sustaining agricultural production and food security in Southern Africa: An improved role for climate prediction? Clim. Chang. 2007, 83, $287-300$. [CrossRef]

22. Bekele, W.; Drake, L. Soil and water conservation decision behaviour of subsistence farmers in the Eastern Highlands of Ethiopia: A case study of the Hunde-Lafto area. Ecol. Econ. 2003, 46, 437-451. [CrossRef]

23. Balcha, Y. Prospects of Transforming Subsistence Agriculture into Sustainable Livelihoods. A Case Study of the Ribb Sub-Catchment, Ethiopia. Master's Thesis, Uppsala University, Uppsala, Sweden, 2013.

24. Fan, S.; Brzeska, J.; Keyzer, M.; Halsema, A. From Subsistence to Profit: Transforming Smallholder Farms; IFPRI: Food Policy Report; International Food Policy Research Institute (IFPRI): Washington, DC, USA, 2013.

25. Bacha, D.; Namara, R.; Bogale, A.; Tesfaye, A. Impact of small-scale irrigation on household poverty: Empirical evidence from the Ambo district in Ethiopia. Irrig. Drain. 2011, 60, 1-10. [CrossRef]

26. Tesfaye, A.; Bogale, A.; Namara, R.E.; Bacha, D. The impact of small-scale irrigation on household food security: The case of Filtino and Godino irrigation schemes in Ethiopia. Irrig. Drain. Syst. 2008, 22, 145-158. [CrossRef]

27. Woldeab, T. Irrigation Practices, State Intervention and Farmers Life-Worlds in Drought-Prone Tigray. Ph.D. Thesis, Wageningen University, Wageningen, The Netherlands, 2003.

28. Gebrehaweria, G.; Regassa, E.N.; Stein, H. Poverty reduction with irrigation investment: An empirical case study from Tigray, Ethiopia. Agric. Water Manag. 2009, 96, 1837-1843.

29. IFAD Special Country Program Phase II. Interim Evaluation; International Fund for Agricultural Development: Addis Ababa, Ethiopia, 2005.

30. Mudima, K. Socioeconomic Impact of Smallholder Irrigation Development in Zimbabwe: A Case Study of Five Successful Irrigation Schemes. In Private Irrigation in Sub Saharan Africa; Sally, H., Abernethy, C.L., Eds.; IWMI: Colombo, Sri Lanka, 2002.

31. Perret, S. Water policies and smallholding irrigation schemes in South Africa: A history and new institutional challenges. Water Policy 2002, 4, 283-300. [CrossRef]

32. Delgado, C.L. Sources of growth in smallholder agriculture integration of smallholders with processors in Sub-Saharan Africa: The role of vertical and marketers of high value-added items. Agrekon 1999, 38, 165-189. [CrossRef]

33. Food and Agricultural Organization of the United Nations (FAO) AQUASTAT. 2005a. Available online: http:/ / www.fao.org/nr/water/aquastat/countries_regions/ZMB/index.stm (accessed on 12 March 2018).

34. Food and Agricultural Organization of the United Nations (FAO) AQUASTAT. 2005b. Available online: http:/ / www.fao.org/nr/water/aquastat/countries_regions/MOZ/ (accessed on 12 March 2018).

35. Food and Agricultural Organization of the United Nations (FAO) AQUASTAT. 2005c. Available online: http:/ / www.fao.org/nr/water/aquastat/countries_regions/MWI/ (accessed on 12 March 2018).

36. You, L.Z. Africa Infrastructure Country Diagnostic: Irrigation Investment Needs in Sub-Saharan Africa; Background Paper 9; World Bank: Washington, DC, USA, 2008.

37. Amede, T.; Desta, L.T.; Harris, D.; Kizito, F.; Xueliang, C. The Chinyanja Triangle in the Zambezi River Basin, Southern Africa: Status of, and Prospects for, Agriculture, Natural Resources Management and Rural Development. WLE Research for Development (R4D) Learning Series 1. 2014. Available online: http:/ /www. iwmi.cgiar.org/Publications/wle/r4d/wle_research_for_development-learning_series-1.pdf (accessed on 28 November 2017).

38. CGIAR Characterization of Areas Targeted for Sustainable Intensification. 2013. Available online: http: / / drylandsystems.cgiar.org/content/characterization-areas-targeted-sustainable-intensification (accessed on 28 December 2017).

39. Food and Agriculture Organization of the United Nations (FAO). Irrigation potential in Africa: A basin approach. In FAO Land and Water Bulletin; FAO: Rome, Italy, 1997; Volume 4, ISBN 92-5-103966-6. Available online: http:/ / www.fao.org/docrep/w4347e/w4347e00.htm\#Contents (accessed on 14 March 2018).

40. Food and Agriculture Organization of the United Nations (FAO). AQUASTAT. Malawi, Zambia and Mozambique. 2006. Available online: http://www.fao.org/nr/water/aquastat/countries_regions/malawi/ index.stm (accessed on 5 March 2018).

41. Peters, P.E. Informal Irrigation in Lake Chilwa Basin: Stream-Bank and Wetland Gardens'; Final Research Report under BASIS-CRSP; University of Wisconsin-Madison: Madison, WI, USA, 2004. 
42. National Statistical Office. National Census of Agricultural and Livestock 2006/2007; Main Report; NSO: Zomba, Malawi, 2010; Available online: http:/ / www.nsomalawi.mw/images/stories/data_on_line/agriculture/ NACAL/Nacal\%20Report.pdf (accessed on 7 March 2018).

43. Malawi Ministry of Agriculture and Food Security (MoAFS). Malawi Agricultural Sector-Wide Approach. In A prioritized and Harmonized Agricultural Development Agenda, 2011-2015; MoAFS: Lilongwe, Malawi, 2011.

44. Evans, A.E.V.; Giordano, M.; Clayton, T. (Eds.) Investing in Agricultural Water Management to Benefit Smallholder Farmers in Zambia; AgWater Solutions Project Country Synthesis Report; IWMI Working Paper 150; International Water Management Institute (IWMI): Colombo, Sri Lanka, 2012; 37p. [CrossRef]

45. Worldfish. Sustainable Water Usage in the Chinyanja Triangle. 2013. Available online: http://www. worldfishcentre.org/our-research/ongoing (accessed on 6 April 2013).

46. Vågen, T.; Winowiecki, L.; Desta, L.; Tondoh, J. The Land Degradation Surveillance Framework Field Guide; World Agroforestry Centre (ICRAF): Nairobi, Kenya, 2010.

47. Chilonda, P.; Otte, J. Indicators to monitor trends in livestock production at national, regional and international levels. Livest. Res. Rural Dev. 2006, 18, 117. Available online: http:/ /www.lrrd.org/lrrd18/8/ chil18117.htm (accessed on 28 November 2017).

48. Eurostat. The EU in the World 2013: A Statistical Portrait; European Union: Luxembourg, 2013.

49. Chianu, J.N.; Tsujii, H. Determinants of farmers' decision to adopt or not adopt inorganic fertilizer in the savannas of northern Nigeria. Nutr. Cycl. Agroecosyst. 2004, 70, 293-301. Available online: https: / /link.springer.com/article/10.1007/s10705-005-0715-7 (accessed on 28 November 2017). [CrossRef]

50. Getacher, T.; Mesfin, A.; Gebre-Egziabher, G. Adoption and impacts of an irrigation technology: Evidence from household-level data in Tigray, Northern Ethiopia. Univ. J. Agric. Res. 2014, 1, 30-34.

51. Asfaw, A.; Admassie, A. The role of education on the adoption of chemical fertilizer under different socioeconomic environments in Ethiopia. Agric. Econ. 2004, 30, 215-228. [CrossRef]

52. Mulugeta, E.; Belay, K.; Legesse, D. Determinants of adoption of physical soil conservation measures in central highlands of Ethiopia: The case of three districts of North Shewa Zone. Agrekon 2001, 40, 313-335. [CrossRef]

53. Adesina, A.A.; Chianu, J. Determinants of farmers' adoption and adaptation of alley farming technology in Nigeria. Agrofor. Syst. 2002, 55, 99-112. [CrossRef]

54. Somda, J.; Nianogo, A.J.; Nassa, S.; Sanou, S. Soil fertility management and socioeconomic factors in crop livestock systems in Burkina Faso: A case study of siting technology. Ecol. Econ. 2002, 43, 175-183. [CrossRef]

55. Knowler, D.; Bradshaw, B. Farmers' adoption of conservation agriculture: A review and synthesis of recent research. Food Policy 2007, 32, 25-48. [CrossRef]

56. Kassie, M.; Zikhali, P.; Manjur, K.; Edwards, S. Adoption of organic farming technologies: Evidence from semi-arid regions of Ethiopia. Nat. Resour. Forum 2009, 33, 189-198. [CrossRef]

57. Woodhouse, P.; Veldwisch, G.J.; Venot, J.P.; Brockington, D.; Komakech, H.; Manjichi, A. African farmer-led irrigation development: re-framing agricultural policy and investment? J. Peasant Stud. 2016, 44, 213-233. [CrossRef]

58. Shah, T.; Verma, S.; Pavelic, P. Understanding smallholder irrigation in Sub-Saharan Africa: results of a sample survey from nine countries. Water Intern. 2013, 38, 809-826. [CrossRef]

59. Serrano, V.M.B.L.; Carter, R.C. Small Scale Irrigation in Angola: Potential and Promise. Outlook Agric. 1991, 20, 3-175. [CrossRef]

60. Kimmage, K.; Adams, W.M. Small-scale farmer-managed irrigation in Northern Nigeria. Geoforum 1990, 4, 4-443. [CrossRef]

61. Carter, R.C. The development of small-scale irrigation in sub-Saharan Africa. J. Theor. Soc. Psychol. 1989, 9, 543-555. [CrossRef]

62. Long, J.S. Regression Models for Categorical and Limited Dependent Variables; Advanced Quantitative Techniques in the Social Sciences Number 7; Sage Publications: Thousand Oaks, CA, USA, 1997.

63. Caswell, M.F.; Zilberman, D. The choices of irrigation technologies in California. Am. J. Agric. Econ. 1985, 67, 224-234. [CrossRef]

64. Shrestha, R.B.; Gopalakrishnan, C. Adoption and diffusion of drip irrigation technology: An econometric analysis. Econ. Dev. Cult. Chang. 1993, 41, 407-418. [CrossRef]

65. Skaggs, R.K. Predicting drip irrigation use and adoption in a desert region. Agric. Water Manag. 2001, 51, 125-142. [CrossRef] 
66. Sureshwaran, S.; Londhe, S.R.; Frazier, P. A logit model for evaluating farmer participation in soil conservation programs: Slopping agricultural land technology on upland farms in the Philippines. J. Sustain. Agric. 1996, 7, 57-69. [CrossRef]

67. Yohannes, G.M. The effects of conservation on production in the Andit Tid Area, Ethiopia. In Soil Conservation for Survival; Kebede, T., Hurni, H., Eds.; Iowa State University Press: Iowa City, IA, USA, 1992.

68. Shiferaw, B.; Holden, S.T. Resource degradation and adoption of land conservation technologies in the Ethiopian highlands: A case study in Andit Tid, North Shewa. Agric. Econ. 1998, 18, 233-247. [CrossRef]

69. Sidibe, M. Farm-level adoption of soil and water conservation techniques in northern Burkina Faso. Agric. Water Manag. 2005, 71, 211-224. [CrossRef]

70. Abera, B.D. Factors Influencing the Adoption of Soil Conservation Practices in Northwestern Ethiopia; Discussion Paper, No. 37; University of Goettingen: Goettingen, Germany, 2003.

71. Namara, R.E.; Upadhyay, B.; Nagar, R.K. Adoption and Impacts of Micro-Irrigation Technologies: Empirical Results from Selected Localities of Maharashtra and Gujarat States of India; Research Report 93; International Water Management Institute: Colombo, Sri Lanka, 2005.

72. Herath, P.H.M.U.; Takeya, H. Factors determining intercropping by rubber smallholders in Sri Lanka: A logit analysis. Agric. Econ. 2003, 29, 159-168. [CrossRef]

73. Singh, B.; Singh, B.N.; Singh, A. Effect of mulch and irrigation on yield of Indian mustard on dry terraces in Alfisols. Indian J. Agric. Sci. 1996, 60, 477-479.

74. Hussain, I.; Namara, R.E.; Madar, S. Water for Food Security for the Poor; A Collection of Thematic Papers; Asian Development Bank: Mandaluyong, Philippines, 2004.

75. Diao, X.; Hazell, P.; Thurlow, J. The role of agriculture in African development. World Dev. 2010, 38, 1375-1383. [CrossRef]

76. Chambers, R. Irrigation against rural poverty. In Socioeconomic Dimension and Irrigation; R.K., Gujar, Ed.; Printwell: Gujarat, India, 1994.

77. Kumar, D. Food Security and Sustainable Agriculture in India: The Water Management Challenge; Working Paper; International Water Management Institute: Colombo, Sri Lanka, 2003.

78. Hussain, I.; Hanjra, M.A. Irrigation and poverty alleviation: Review of the empirical evidence. Irrig. Drain. 2004, 53, 1-15. [CrossRef]

79. Rowe, J.W.; Andres, R.; Tobin, J.D.; Norris, A.H.; Shock, N.W. The effect of age on creatinine clearance in men: A cross-sectional and longitudinal study. J. Gerontol. 1976, 31, 155-163. [CrossRef] [PubMed] 